\title{
Descrições de paisagens \\ construindo vazios humanos e territórios indígenas na capitania de São Paulo ao final do século XVIII*
}

\author{
Landscape descriptions \\ building wildemess and Indian temitories at the \\ Captaincy of São Paulo at the end of the $18^{\text {th }}$ Century
}

\author{
DORA SHELLARD CORRÊA \\ Doutora - FFLCH-USP \\ UNIFIEO - Centro Universitário Fieo \\ Av. Santa Lúcia n. 25. \\ 06355-450 Carapicuíba - São Paulo - Brasil \\ pdscor@uol.com.br
}

RESUMO Neste artigo, discutimos a reconstituição de paisagens pretéritas a partir de documentos escritos. Particularmente nos debruçamos sobre as paisagens reveladas pela documentação produzida pelos comandantes das expedições aos rios Tibagi, Iguaçu e Ivaí, acontecidas entre 1768 e 1774, comandadas por Afonso Botelho de San Paio e Sousa a mando D. Luís Antônio de Sousa Botelho Mourão - Morgado de Mateus -, Capitão General e Governador da capitania de São Paulo entre 1765 e 1775.

Palavras chave paisagens, fronteira, Campos de Guarapuava - PR

ABSTRACT In this article we discuss the reconstitution of past landscapes from written documents. Particularly, we studied the landscapes revealed by the documentation produced by the commanders of expeditions to the rivers Tibagi, Iguaçu and Ivaí. These expeditions happened between 1768

Artigo recebido em: 20/08/2007. Aprovado em: 10/12/2007. 
and 1774 and were commanded by Alfonso Botelho de San Paio and Sousa, by order of D. Luís Antônio de Sousa Botelho Mourão - Morgado de Mateus ,- General and Governing Captain of the captaincy of Sao Paulo between 1765 e1775.

Key words landscapes, frontier, Campos de Guarapuava-PR

O brasileiro concebe as terras apossadas e utilizadas pelos índios entre os séculos XVI e XX da mesma forma que ela foi descrita por Pero Vaz de Caminha em 1500. Apesar de se afirmar serem elas habitadas, a paisagem retratada leva o leitor a imaginar uma natureza virgem. Se há muito já se criticou o caráter político-ideológico da visão sobre os índios como bárbaros e sobre as terras, especialmente além da fronteira da colonização européia, como desertas, a insistência em descrever o espaço físico em separado de sua organização social naturaliza esse espaço e restaura a concepção sobre a imaturidade das culturas indígenas. Essa naturalização, conforme Willian Cronon, ${ }^{1}$ significa a negação da História e implica uma desapropriação das pessoas que vivem nessas terras. Chiara Vangelista, ${ }^{2}$ referindo-se à diversidade de processos de ocupação da fronteira, no caso, do Brasil, lembra que a afirmação de terras vazias serve como justificativa para a tomada de áreas povoadas por populações consideradas marginais a um dado projeto político.

A quase inexistência, até recentemente, de obras historiográficas que descrevessem a paisagem da fronteira como humanizada ${ }^{3}$ explica que, apesar da crítica à idéia de um vazio social e cultural, essa representação continue a se reproduzir no imaginário do brasileiro. A história ambiental, por também enfocar o meio ambiente por meio do estudo da paisagem, tem muito a contribuir, recompondo essa memória social.

1 CRONON, William. Introduction: in search of nature. In CRONON, W. (ed.) Uncommon ground. Rethinking the human place in nature. New York: W. W. Norton \& Company, 1996, p.23-56.

2 VANGELISTA Chiara. Terra e fronteira no Brasil: culturas, etnias, sociedade. História Unisinos, São Leopoldo, v.4, n.2, p.55-72, 2000.

3 A partir da década de 1990, vem se observando o crescimento de investigações que apresentam descrições da fronteira humanizada. Os seguintes estudos foram de grande ajuda para a elaboração deste artigo: MALDI, Denise. De confederados a bárbaros: a representação da territorialidade e da fronteira indígenas nos séculos XVIII e XIX. Revista de Antropologia, São Paulo, v.40, n.2, p.183-221, 1997; MONTEIRO, J ohn Manuel. Negros da terra. São Paulo: Cia das Letras, 1990; VANGELISTA, Chiara. Los Payguá entre Asunción y Cuiabá: formación y decadência de uma frontera indígena (1719-1790). In: GARCIA J ORDAN, Pilar y IZARD, Miquel. (Coords.) Conquista y resistência em la história de América. Barcelona: Publicaciones Universidad de Barcelona, 1992, p.151-165; GARCIA J ORDAN, Pilar y IZARD, Miquel. Terra e fronteira no Brasil: culturas, etnias, sociedade. História Unisinos, São Leopoldo, v.4, n.2, p.55-72, 2000. 
Neste artigo, vamos discutir a reconstituição de paisagens ${ }^{4}$ pretéritas a partir de relatórios, cartas, diários, enfim, de textos. Sustentamos que, antes de debruçar-se sobre as ciências ambientais, o historiador deve se voltar a questões discutidas pela própria historiografia, às noções norteadoras de sua forma de abordagem e refletir sobre o documento. 0 homem é um protagonista do enredo, seja produzindo os dados examinados, o relatório ou a carta, seja como ator no relato. 0 pesquisador, portanto, chega ao seu objeto de estudo - a mata, o rio, o clima e a paisagem - pelos olhos e pela visão de mundo de outro homem, o seu testemunho.

Pelo esboço de um cenário, que envolve a percepção, interpretação, seleção e organização dos elementos vegetais, minerais, geográficos e culturais visualizados, o testemunho apresenta um conceito sobre a organização social do espaço, o que implica presenças e ausências tanto humanas quanto naturais no quadro exposto. Essas descrições podem sugerir territórios como também locais destituídos de domínio político, militar ou cultural. 0 fato de se constatar a invenção desses territórios ${ }^{5} \mathrm{e}$ dessas áreas naturais é um aspecto importante de se ter em conta quando se objetiva investigar as paisagens passadas.

Neste trabalho, vamos examinar as paisagens reveladas pela documentação produzida pelos comandantes das onze expedições aos rios Iguaçu, Ivaí e Tibagi, acontecidas entre 1768 e 1774, comandadas por Afonso Botelho de San Paio e Sousa a mando D. Luís Antônio de Sousa Botelho Mourão - o Morgado de Mateus -, Capitão General e Governador da capitania de São Paulo entre 1765 e $1775 .{ }^{6}$ Esses relatos induzem 0 leitor a imaginar tanto vazios humanos e, portanto, culturais, quanto um território indígena, ${ }^{7}$ Xakclan (Kaingang), dentro das fronteiras fixadas pelo Tratado de Madrid. Essa elaboração resultou do fato de se projetar a per-

4 Designamos paisagem o conjunto de elementos concretos de um local que são visualizados, interpretados, compreendidos e depois descritos num documento. Portanto, diferentemente do que se pode definir como uma história da paisagem ou como os geógrafos, pré-historiadores e arquitetos procedem, nosso objeto de análise não é o que nós enxergamos num dado espaço físico e atribuímos sentido, mas a representação de um cenário que outro indivíduo avistou, traduziu e anotou. Para uma discussão semelhante Ver: STEPAN, Nancy Leys. Picturing tropical nature. London: Reaktion Books, 2001.

5 Cabe esclarecer que território está sendo definido, seguindo Claude Raffestin, como espaço físico apropriado e dominado concreta e abstratamente. Ver: RAFFESTIN, Claude. Por uma geografia do poder. São Paulo: Ática, 1993. Falamos em território inventado quando quem o concebe, caracterizando-o e delimitando-0, é alguém externo à comunidade à que ele se refere e que o vivencia.

60 estudo mais completo sobre o governo de Morgado de Mateus é: BELLOTO, Heloísa L. Autoridade e conflito no Brasil colonial: o governo do Morgado de Mateus em São Paulo (1765 - 1775). 2a.ed. rev. São Paulo: Alameda, 2007. Sobre essas campanhas, algumas análises já foram publicadas. Ver: BELLUZO, Ana Maria Moraes et. al. Do contato ao confronto. A conquista de Guarapuava no século XVII. São Paulo: PNP Paribas, 2003; KOK, Glória. O sertão itinerante. Expedições da capitania de São Paulo no século XVIII. São Paulo: Hucitec, 2004. A respeito do impacto dessas expedições sobre os Kaingang e sua resistência ao avanço da colonização até o início do século XX, ver: MOTA, Lúcio Tadeu. A guerra dos índios Kaingang. A história épica dos índios Kaingang no Paraná (1769-1924). Maringá: Universidade de Maringá, 1994.

7 Marta Rosa Amoroso publicou um estudo interessante sobre documentação do século XVIII, que inventa um território Mura na Amazônia. Ver: AMOROSO, Marta Rosa. Território do medo: notas sobre a utilização da crônica setecentista como fonte da etnografia Mura. In: NIEMEYER, Ana Maria e GODOI, Emília Pietrafesa de. (ed.) Além dos territórios. Para um diálogo entre a etnologia indígena e os estudos rurais e os estudos urbanos. Campinas: Mercado das Letras, 1998, p.251-269. 
cepção de territorialidade dos agentes do Estado colonial sobre o espaço ocupado e perambulado por grupos indígenas variados. Os comandantes decodificaram aquela paisagem a partir dos signos de domínio e de posse da terra característicos de sua própria sociedade. ${ }^{8}$

A maior parte da documentação aqui analisada compõe um conjunto intitulado A notícia da conquista e descobrimento dos sertões do Tibagi. ${ }^{9} 0$ trabalho foi assinado por Afonso Botelho de San Paio e Sousa e parece ter sido originalmente divulgado depois da coroação de D. Maria I, ocorrida em 1777, a quem é dedicado. 0 volume de documentos contém o relatório geral das expedições, diários de campanhas, notícias, roteiros, cartas, listas de gente, de apetrechos levados e de animais conduzidos. Cada uma das campanhas deveria estar relatada num diário, conforme as instruções dadas a cada comandante.

Há de levar em conta, na análise dessa documentação, que havia uma tensão grande entre o Capitão-General - Don Luís Antônio de Sousa Botelho Mourão e o Vice-Rei - D. Luís de Almeida Portugal Soares de Alacão Eça e Mello Silva e Mascarenhas - o Marques de Lavradio, (1769-1779). Este, preocupado com o fortalecimento da capitania do Rio Grande, após o desmoronamento do Tratado de Madrid com a conquista da colônia de Sacramento pela Espanha (1762), e com a pressão dos colonos espanhóis sobre o extremo Sul do território português. Marquês de Lavradio censurou Morgado de Mateus pelo desvio de recursos financeiros e humanos necessários à defesa do Sul, com prioridades exclusivas de sua capitania, entre elas, as campanhas ao vale do Tibagi. ${ }^{10}$ Afonso Botelho de San Paio e Sousa, entretanto, foi censurado pela forma como tratou os Kaingang de Guarapuava. Os textos que formam a Notícia, como outros historiadores já pontuaram, ${ }^{11}$ provavelmente foram reunidos para justificar e defender a política de Morgado de Mateus e, especialmente, a atuação de Afonso Botelho. 0 que estabelece uma conexão entre esses variados papéis é 0 relatório geral do comandante, que informa sinteticamente sobre cada uma

8 Está fora do escopo deste artigo discutir se realmente existia um território Xakclan, vivenciado por estes índios, e se ele se conformava com a idealização dos comandantes das campanhas aos sertões do Tibagi. Kimiye Tommasino analisou a territorialidade Kaingang, utilizando estudos atuais e fontes históricas, inclusive a documentação sobre as campanhas de Afonso Botelho. Ver: TOMMASINO, Kimiye. Território e territorialidade Kaingang. Resistência cultural e historicidade de um grupo J ê. In: MOTA, Lucio Tadeu; NOELLI, Francisco S.; TOMMASINO, Kimiye. (ed.) Uri e Wãxi. Estudos interdisciplinares dos Kaingang. Londrina: UEL, 2000, p.191-226.

9 Notícia da conquista e descobrimento dos sertões do Tibagi, na capitania de S. Paulo, no Governo do general Don Luís Antônio de Sousa Botelho Mourão, conforme as ordens de Sua Majestade. 1768-1774. Anais da Biblioteca Nacional. Rio de J aneiro, v.76, 1956.

10 Heloísa Belloto discute as divergências entre Morgado de Mateus e Marques de Lavradio e o governo metropolitano. 0 desentendimento chega ao seu clímax em fins de 1771, resultando na substituição do Governador da capitania de São Paulo, em 1775. Ver: BELLOTO, Heloísa Liberalli. Autoridade e conflito no Brasil colônia: o governo do Morgado de Mateus em São Paulo (1765-1775).

11 SEVCENKO, Nicolau. O ciclo de Miranda: utopia indigenista no Brasil pombalino. In: BELLUZO, Ana Maria de Moraes et. al. Do contato ao confronto. A conquista de Guarapuava no século XVII. São Paulo: PNP Paribas, 2003, p.15-23. 
das onze expedições, elaborado após 1775,12 no governo do general Martin Lopes Lobo de Saldanha, sucessor de Don Luís Antônio. No documento, em tom elogioso, 0 autor apresenta informações sintéticas sobre cada uma das onze expedições. Foi após a entrada desse Governador-Geral que se deu a destituição do comandante português do posto de coronel ao qual havia sido elevado em 1774. O conjunto de informes introduzido por esse relatório indica que as operações tinham um sentido geral que atendia a interesses da capitania de São Paulo.

A conjuntura política em que aconteceu a publicação do Notícias nos leva a atentar para o fato de que alguns dados foram intencionalmente acentuados e outros omitidos. Porém, eles não são suficientes para explicar a imagem que se tinha sobre o sertão como um deserto demográfico e cultural, assim como para entender a imaginação de um território indígena.

Embora o título do conjunto seja Notícias do vale do rio Tibagi, são três os principais rios navegados: o Tibagi, o Ivaí e o Iguaçu. Visivelmente, seja pelos roteiros, seja pelas ordens dadas e pelos diários e cartas, o reconhecimento dos campos de Guarapuava e de seus habitantes foi um dentre outros propósitos para a organização das campanhas. Essas ações atendiam ao projeto político de Morgado de Mateus para a capitania de São Paulo. Este, entre outros aspectos, implicava, por um lado, defender as fronteiras com as posses espanholas pelo controle, mapeamento, estabelecimento de marcos de posse e da ocupação efetiva de terras anteriormente conquistadas pelos colonos e jesuítas espanhóis. Por outro, assegurar e viabilizar a expansão de fazendas de invernada nos campos gerais e conquistar os campos de Guarapuava.

Fala-se também que um importante estímulo a essas ações foi a crença na existência de ouro e pedras preciosas no rio Tibagi. Contudo, apesar de até constar, numa das ordens dadas, que os comandantes deveriam marcar os locais onde localizassem ouro, a atenção central de Don Luís Antônio direcionava-se para as terras e, especialmente, para os índios de Guarapuava. Conforme as instruções que orientavam as campanhas, os soldados haviam de empenhar-se em reduzir "o gentio ao grêmio da Ig reja, e introduzir a fé de Nosso Senhor J esus Cristo nestes grandíssimos sertões"13 e levar os índios a obedecer ao rei de Portugal. A organização e as ações dessas expedições militares indicam que as autoridades portuguesas queriam conquistar o que concebiam como um território indígena existente dentro das fronteiras oficiais da colônia.

As onze expedições envolveram para mais de 503 pessoas entre oficiais, soldados pagos, camaradas, capelães e escravos. A maioria era gente de

12 Afonso Botelho faz referência, nesse relatório, ao ataque da freguesia de Nossa Senhora da Esperança, ocorrido em 1775. Notícia da conquista e descobrimento dos sertões do Tibagi, p.24.

13 Notícia da conquista e descobrimento dos sertões do Tibagi, p.79. 
Cananéia, de Iguape, dos Campos Gerais e de Curitiba. A arregimentação da população pobre, necessária para completar os quadros, foi dificultosa devido a sua dispersão. As mortes e deserções foram problemas sérios durante as campanhas.

A primeira, segunda, terceira e quinta expedições, ainda que se informasse ser sua meta final descobrir os campos de Guarapuava, reconheceram o Ivaí e a parte desconhecida formalmente do Iguaçu. Segundo Heloísa Belloto, o Ivaí se tratava apenas do rótulo, objetivava-se o Iguatemi, área em disputa com os espanhóis. ${ }^{14} \mathrm{O}$ propósito da quarta e da sexta campanha era descobrir os campos de Guarapuava. A sétima, oitava e nona, encontrar o melhor caminho até eles. A décima, investigar a área, localizar os índios que a habitavam e reduzi-los. E a décima primeira, marchar sobre os campos e apossar-se deles. Porém, esta ultima foi abortada a mando de D. Luís Antônio de Sousa quando em andamento.

Na décima expedição, acontecida em 1771/72, o próprio comandante geral acompanhou seus comandantes e soldados na penetração e reconhecimento dos campos de Guarapuava. Deu-se, nessa entrada, um confronto entre os soldados e os Xakclan que habitavam o local, resultando na retirada dos súditos da coroa portuguesa e o abandono temporário daquele movimento de avanço. Os homens de Afonso Botelho retornaram aos campos, em fins de novembro de 1773, revelando uma conduta visivelmente preparada tanto quanto às armas e quanto à experiência de seu comandante para enfrentar os índios. Visitaram os locais onde haviam estabelecido os acampamentos, colocado marcos de posse e enterrado os soldados mortos no enfrentamento acontecido na campanha anterior. Verificaram os campos novamente e a aldeia em que foram convidados dos Xakclan em 1772, antes do conflito. Ao se defrontarem com os índios, interpretaram seus movimentos como apreensivos e ameaçares: "e topando com eles os persuadiu a que chegassem, o que deles não pôde alcançar (...) Ihes deu um surtum de baeta (...) cuja a recompensa foi dispararem uma seta apontada para 0 chão, mostrando os semblantes embravecidos". ${ }^{15}$ A parentemente acuados, retiraram-se após um embate quando, segundo registros da época, reagiram cruelmente. Conforme o relato do próprio comandante:

Deram princípio ao seu projeto, expulsando alguas setas contra a nossa gente, e vendo esta o nenhum remédio que podiam ter para salvar as vidas, se resolveu a descarregar sobre aquêles bárbaros ua descarga de outros tantos tiros quantos eram os homens, que ali se achavam. ${ }^{16}$

14 BELLOTO, Heloísa L. Autoridade e conflito no Brasil colônia.

15 Notícia da conquista e descobrimento dos sertões do Tibagi, p.282.

16 Notícia da conquista e descobrimento dos sertões do Tibagi, p.285. 
Após o confronto, recuaram até o acampamento Nossa Senhora da Esperança (hoje Entre Rios), fora dos campos, onde estava sediado o resto da campanha com seu comandante, Afonso Botelho. Este já havia recebido ordens para auxiliar na proteção das capitanias do Sul. Em abril de 1774, o ministro e secretário de Estado dos Negócios da Marinha e Domínios Ultramarinos, Martinho de Melo e Castro, ordenou o encerramento das ações nos sertões do Tibagi, motivado, entre outras razões, pelas denúncias de violência com que os homens de Afonso Botelho haviam tratado os Xakclan, "quando as ordens expressas da Corte mandam evitar a menos opressão ou violência e harmonizar o convívio". ${ }^{17}$ Pretendia-se ter os índios como guardas das fronteiras da colônia, tanto que, em algumas ordens vindas do mesmo Morgado de Mateus, havia a liberalização do casamento dos soldados com as índias e a determinação de tratar os indígenas com "afabilidade animando-os, e convidando-os com alguas dádivas, para os capacitar a serem nossos amigos". ${ }^{18}$

Sobre a campanha de que participou Afonso Botelho - a mais bem documentada, além do relatório escrito, mapa e de ofícios vários - foi pintada uma série de quarenta aquarelas (encontram-se preservadas somente trinta e nove) por J oaquim J osé de Miranda, de quem não se tem informações. ${ }^{19}$ As telas retratam o contato da expedição com os Xakclan, seu primeiro encontro, a visita à aldeia indígena e, posteriormente, ao acampamento dos soldados, a investida dos índios e a fuga da tropa. Executadas, possivelmente, anos depois da expedição e do próprio relatório, as aquarelas encontram-se hoje separadas do documento oficial, incorporadas à coleção Beatriz e Mário Pimenta Camargo, que tem sido exposta ao público. A documentação escrita serviu de argumento para as aquarelas

Os diários sobre essas campanhas nos revelam que havia um conhecimento acumulado sobre o sertão. Os soldados seguiram roteiros já percorridos, assim como utilizaram alguns mapas anteriormente elaborados. Picadas e caminhos foram abertos ou encontrados. Já estavam denominados quase todos os principais afluentes do Paraná, as cachoeiras proeminentes, serras e as grandes áreas de campos: rio Tibagi, rio Registro ou Iguaçu, serra de Apucarana e campos de Guarapuava. Um mapa de 1755 revela parte dos conhecimentos que já se tinha sobre os sertões do Tibagi, inclusive algumas picadas (Mapa 1, picada). Os cursos d'água, morros e locais singulares, até então ignorados ou pouco conhecidos pelo Estado, foram nomeados ou renomeados e registrados nas cartas geográficas com designações como as do Reino, conforme as ordens oficiais - rio D. Luís (atual Ivaí), rio Mourão, rio J ordão, Pouso da Fome.

17 ARRUDA, J osé J obson de Andrade. (ed.) Documentos manuscritos avulsos da capitania de São Paulo. Catálogo 2 (1618-1823) - Mendes Gouveia. Bauru: Edusc; São Paulo: Imprensa Oficia/ Fapesp, 2002, p.420.

18 Notícia da conquista e descobrimento dos sertões do Tibagi, p.79.

19 BELLUZO, Ana Maria Moraes et.al. Do contato ao confronto. 


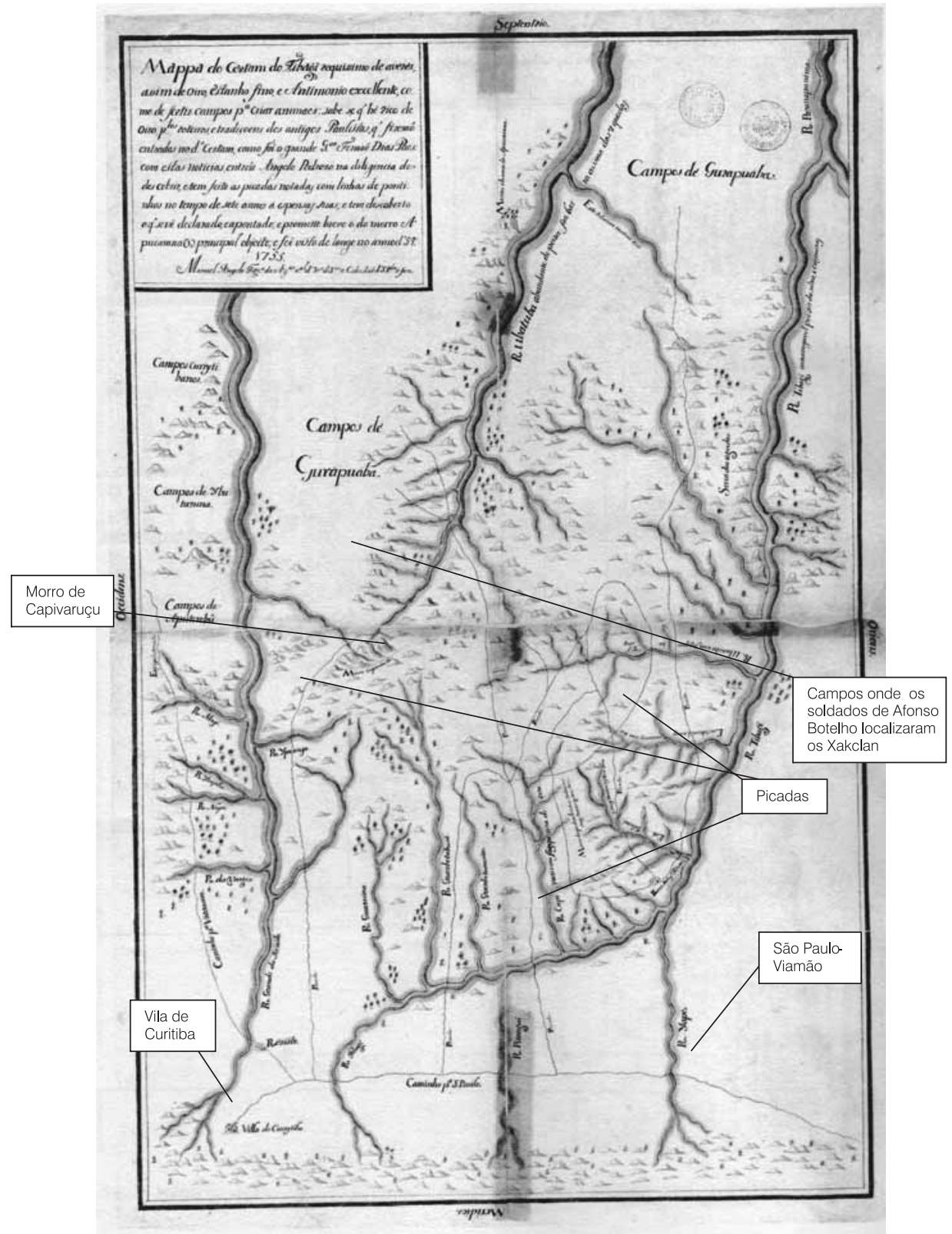

Mapa 1: Sertão do Tibagi em 1755

Fonte: ARRUDA, J obson de Andrade (coord.). Documentos manuscritos avulsos da capitania de São Paulo. Catálogo I (1644 - 1830). Bauru: Edusc; São Paulo: Fapesp/Imesp, 2000, p.28. 
Os homens de Afonso Botelho Mourão localizaram os campos de Guarapuava em 1770. Possuíam noções a respeito de sua direção, caminhos, cursos d'água, cachoeiras, serras que cruzariam e populações indígenas que encontrariam naquela parte do Paraná, então capitania de São Paulo. Ao longo do trajeto que seguiram, os comandantes fizeram referências constantes a informações dos "antigos" sertanistas que perambularam pelo local no passado, às vezes há mais de um século. Um deles foi Luís de Góis Sanches que, em 1641, andando pelos lados do morro de Capivaruçu, próximo às nascentes do Ivaí (Mapa 1, morro de Capivaruçu), encontrou índios com muitas folhetas de ouro. ${ }^{20}$

Partindo daquelas notícias, os comandantes decidiam sobre as meIhores direções a seguir. As terras, no percurso, que se informava estarem habitadas por grupos indígenas, foram evitadas, assim como - mas às vezes tardiamente - as áreas sujeitas à malária. Não é de estranhar que a fronteira mostrada por esses relatórios parece deserta, uma paisagem com sinais esparsos e isolados de interferência humana. 0 relato de Domingos Lopes Cascais, comandante da primeira expedição, que desceu 0 rio Registro (Iguaçu) entre dezembro de 1768 e março de 1769, é exemplar nesse sentido. Informou não haver encontrado sinal algum de índios em seu trajeto: "isto é o que vimos nesta diligência até chegarmos ao porto, onde nos tínhamos embarcado, 3 meses menos um dia, sem em todos esses sertões vermos sinais alguns de gentio, nem são matos capazes de os sustentar". ${ }^{21}$ Eram caminhos seguros para atravessar, pois o cenário, traduzido segundo suas noções de territorialidade, indicava ausência de domínio, como já era esperado.

Poucos são os casos em que, à exceção dos campos de Guarapuava, localizaram-se indícios de ocupação indígena permanente na época. Mesmo assim, esses locais estavam desertos. 0 que expuseram, foram vestígios que mostravam haver gente perambulando pelo sertão e sinais que sugeriam existir grupos indígenas em área distante.

Durante a segunda expedição (1769-1770), comandada por Estevão Ribeiro Baião, uma das esquadras, a de Inácio da Mota, que se perdeu ao seguir o rio Capivari, na bacia do Tibagi, encontrou uma picada de índio já antiga, uma roça indígena, uma abelheira queimada por índio, um fogão e uma panela estragada. Apesar de enxergarem ao longe fumaça de fogos, ${ }^{22}$ continuaram seu caminho, sem se interessarem em descobrir os ranchos indígenas. Bruno da Costa Filgueira, comandante da quarta expedição, justificando-se sobre o lapso que cometeu ao haver comunicado, antes de comprovar, que tinha chegado aos campos de Guarapuava porque ouvira

20 Notícia da conquista e descobrimento dos sertões do Tibagi, p.134.

21 Notícia da conquista e descobrimento dos sertões do Tibagi, p.75.

22 Notícia da conquista e descobrimento dos sertões do Tibagi, p.191, 192. 
barulho de gado e vira fogos indígenas no horizonte, relatou que: "sem que possa argüir o enganar-se (...) nem das fumaças porque certamente as viu, e sem contravenção se pode crer, e se capacitam, o que tem noticia daquele sertão, porque seguindo-se sobre os mesmos saltos em pouca distância os montuosos campos de Aputerevu há 70 anos vistos povoado de gentio". ${ }^{23}$ Como notou que estava enganado, deixou de averiguar os fogos. Essas ações esclarecem que a meta era examinar os caminhos seguros a seguir pelos vales do Tibagi, Ivaí e Iguaçu para atingir os campos de Guarapuava, assim como demarcar as áreas disputadas com os espanhóis.

Fora dos campos de Guarapuava a menção a sinais que revelavam ocupação permanente ou a simples andança por aqueles sertões, sempre remetem o leitor ao passado. São interferências pretéritas na paisagem que chamam a atenção pelo fato de seus autores estarem sempre ausentes do cenário controlado pela natureza. Examinando restos de fogueiras que encontrou próximo à margem do rio Grande do Registro (Iguaçu), ${ }^{24} \mathrm{O}$ comandante da quarta expedição, Bruno da Costa Filgueiras, no final de 1769, chega à conclusão de que o grupo responsável pelo fogo viajava pelo rio e vinha para a margem para preparar o jantar. Várias cenas descritas acentuavam a imagem de um vazio humano como as plantas que avançavam sobre as ruínas de uma vila do século XVII, uma panela arruinada pelo tempo e um fogão e uma abelheira aberta abandonados.

A terceira expedição, comandada pelo Capitão Francisco Lopes da Silva, seguindo pelo rio D. Luís (Ivaí) localizou, no início de 1771, na confluência com o rio Mourão, o que restou da Vila Rica do Espírito Santo, vila espanhola destruída pelos bandeirantes no início do século XVII.

Essas ruínas, de cujo posicionamento se tinha uma idéia prévia, mostravam, segundo o comandante informou, o traçado básico da povoação: as ruas, esquinas e becos. Onde deveriam ter existido as casas e templos, havia pilhas de telhas. 0 comandante acreditava que fora maior do que Santana do Parnaíba. A vegetação tomou o espaço, árvores de grande porte ocuparam o meio das ruas. Entre o mato, podiam-se descobrir cidreiras, laranjeiras e limoeiros. Aliás foi a visão dessas plantas também espalhadas um pouco mais para o interior da mata que deu, aos soldados, a certeza de que estavam próximos às ruínas coloniais. A sensação, para quem lê 0 relato, é a de um local que permaneceu vazio desde o seu abandono pelos espanhóis. As descrições acentuam detalhes das obras, que remetem a como deveria ter sido a vila no passado e como poderia ser no futuro com a sua reocupação pelos soldados e seus familiares. 0 que aconteceu nesse meio tempo é interpretado e narrado como uma ação da natureza: as

23 Notícia da conquista e descobrimento dos sertões do Tibagi, p.102.

240 rio Iguaçu aparece nos relatórios das expedições aos sertões do Tibagi tanto como rio Registro, rio Grande e rio Grande do Registro. Mas também já está referido como Iguaçu em mapas da época. 
plantas tomaram as construções, o que induz a supor a ausência humana e de cultura; portanto, de História. O comandante apresentou, em seu relato, um local caracterizado pelo domínio da natureza.

A imagem de vazio demográfico e cultural daqueles sertões é reforçada pela sugestão de que a destruição da vila, deixada pelos espanhóis no século XVII, foi resultado da ação do tempo e do avanço da vegetação sobre ela. A referência a telhas de barro e a ruas, esquinas e becos, signos representativos de civilização, tomados pela natureza, dá força à idéia de que, mesmo que houvesse índios naqueles vales, Vila Rica do Espírito Santo era ignorada por eles.

Também chama a atenção nessas narrativas, a falta de referências sobre ocupações estáveis de famílias de colonos no sertão. Afinal uma das grandes preocupações de Morgado de Mateus era com a dispersão dos habitantes. ${ }^{25}$ Encontraram-se algumas poucas alusões de sertanistas viajando pelos sertões do Tibagi. Em julho de 1769, a companhia do capitão Estevão Ribeiro Baião encontrou com J oão Pais Domingues, seus filhos, J oão e Bartolomeu, e um escravo que saíam do sertão. Em fins de 1769 (outubro ou novembro), Bruno da Costa Filgueira localizou uma picada próxima ao rio Grande (Iguaçu), que acreditava ser de "gente doméstica", pois os cortes eram feitos com ferro. Havia tanto rastros recentes - revelando que seus produtores deveriam estar caminhando proximamente - como marcas deixadas há muito tempo. A única menção a uma moradia de colono indicava estar ela construída na boca do sertão. No primeiro braço do rio Capivari, afluente do Tibagi, foi identificada a tapera que pertenceu a Pantalião Pedroso.

Embora a abertura do vale do Tibagi para povoamento, oficializada pelo bando de 19 de agosto de 1770, assinado por Don Luís Antônio de Sousa Botelho Mourão, ${ }^{26}$ não tenha surtido efeito, os documentos indicam ter havido colono que pediu autorização para entrar no sertão, como Cláudio Forquim de Camargo, em finais de 1770. José Luís Álvares e Pedro Gomes, com parentes e agregados, receberam licença para penetrar com o comandante da nona expedição, Francisco Martin Lustosa, em fevereiro de 1771. Além deles, acompanharam essa expedição o Capitão J acinto J osé de Abreu, com camaradas, escravos e gente forra, num total de nove pessoas; Antônio Rodrigues foi acompanhado por dois escravos e mais cinco aventureiros. Este comandante, naquele ano, iniciou roças no sítio que viria a formar, em 1773, a freguesia de Nossa Senhora da Esperança (cidade de Entre Rios), a meio caminho entre os campos de Guarapuava e os Campos Gerais.

25 METCALF, Alida C. Family and frontier in colonial Brazil. Santana de Parnaíba, 1580 - 1822. Austin: University of Texas, 2005.

26 Notícia da conquista e descobrimento dos sertões do Tibagi, p.130. 
Somente na décima expedição e na décima primeira, que aconteceram respectivamente em 1772 e 1774, os soldados encontraram ald eias, roças e caminhos interligando-as, ou seja, sinais de ocupação presente, generalizados numa área extensa. Embora o encontro com os Xakclan tenha gerado um sobressalto, e a localização exata de suas povoações fosse desconhecida, afirmações como: "como senhores da casa sabem das entradas e saídas" e "reconhecendo-se terra de gentio"27 fazem pressupor a existência de um espaço físico ocupado e dominado pelos índios, ou seja, pertencente a um território indígena.

Em Guarapuava, os soldados examinaram toda a área e foram ao encontro dos índios ao invés de evitá-los, como procederam até então. Com o auxílio de descrições e de mapa (Mapa 2), os comandantes detalharam os campos, particularmente, as áreas onde estavam situadas as habitações indígenas (Mapa 2, E). A atenção estava centrada nas interferências humanas na paisagem. Os relatos possibilitaram inferências sobre a densidade populacional. Descreveram um local ambientalmente rico, com muita caça e bons matos para o gado e densamente ocupado, explorado e dominado pelos Xakclan. A descrição a seguir, elaborada em 1772, ilustra a determinação em localizar os índios, caracterizar suas moradias, roças, paióis, caminhos. Viabilizava-se, dessa forma, o cálculo da densidade demográfica e a solidez de seus estabelecimentos quanto a condições de sobrevivência física e militar:

Descobriu-se, de um alto, um grande alojamento dos índios (...) Caminharam direitos ao alojamento (...) toparam um pequeno rancho com algum milho em jacazes, e mais nada. Neste lugar estava plantada ua grande roça bem limpa, e posta com tal economia, que levava excesso às nossas; seria de meio alqueire de milho de planta. (...) Deram volta (...) acharam outra roça maior já com espiga, e (...) houve bastante fruta a que chamam guarirobas (...) Apearam-se no terreiro, correram as casas, e em nenhua acharam cousa nova, mais que ua arara, um machado de pedra, muitos porongos, cestinhos, e princípios de tessumes de pano, cujo fio é várias cores; muita carne em jiraus, e algua ao fogo em panelas (...) acharam quarenta e seis jacazes de milho, e três de farinha, pouco feijão, pilões bem feitos com mãos de pedra, muitos dentes de caça enfiados como rosário, peles dalguns bichos (...)..$^{28}$

O diário onde se encontra a descrição acima supostamente estava acompanhado pelas aquarelas de J oaquim J osé de Miranda, a que nos referimos no início deste artigo. As estampas, entretanto, apresentaram 0 arranchamento Xalkclan como muito pobre quanto às interferências humanas na paisagem, contrastando com os relatos escritos. Faltam artefatos

27 Notícia da conquista e descobrimento dos sertões do Tibagi, p.232.

28 Notícia da conquista e descobrimento dos sertões do Tibagi, p.59, 60. 
como panelas, porongos, cestas, assim como as roças ou paióis. A aldeia encontra-se em meio a um campo aberto, com uma mata ao fundo, uma área destituída de signos representativos de cultura. Por essa razão se duvida que J oaquim de Miranda tenha participado dessas campanhas, ou que essas pranchas revelem mais do que a imaginário que se tinha sobre os índios do Brasil.

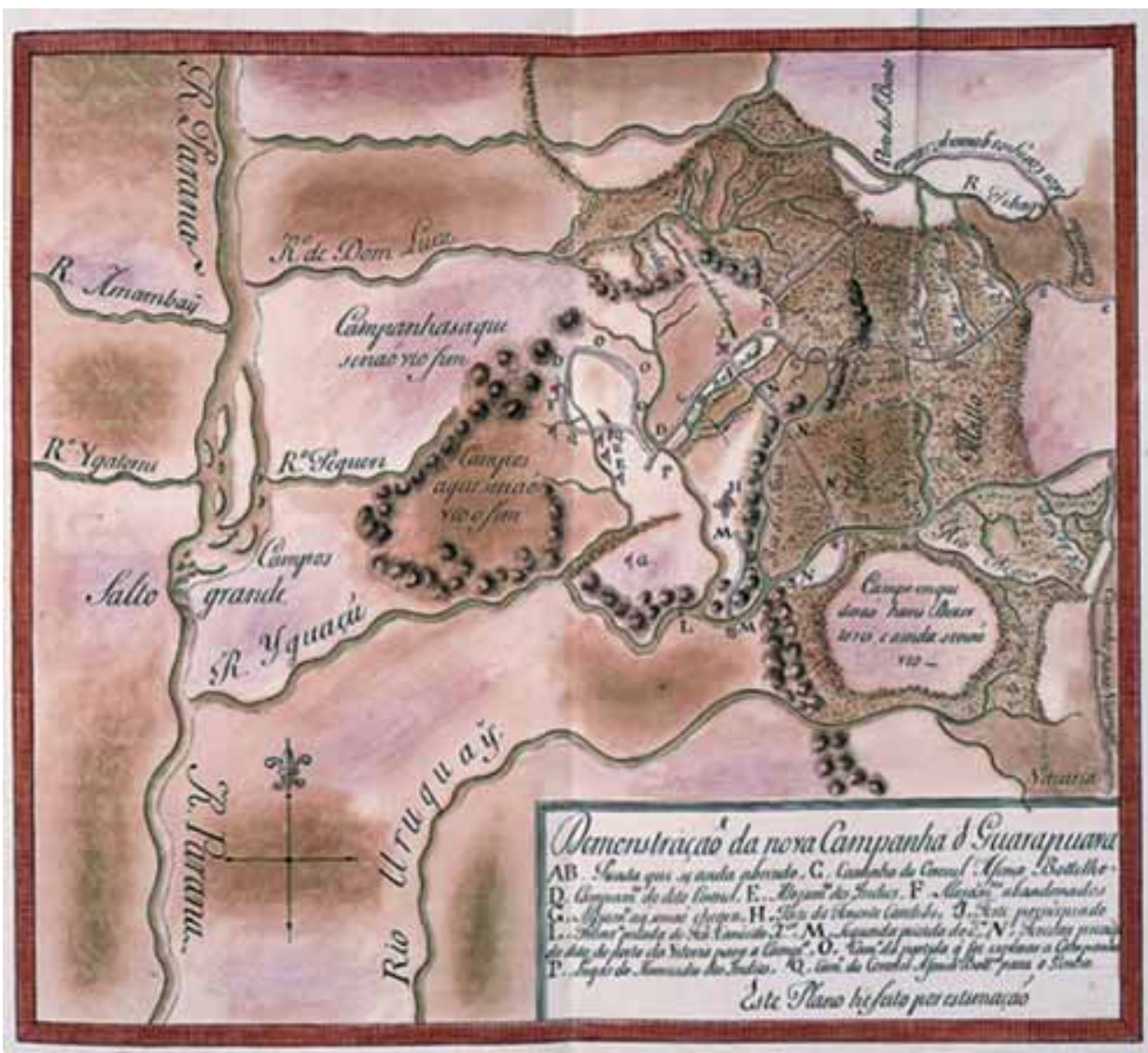

Mapa 2: Demonstração da nova campanha de Guarapuava, 1772

Fonte: IEB/USP - Instituto de Estudos Brasileiros da Universidade de São Paulo. Coleção lan de Almeida Prado. Cromos. Cromo n.76, códice n.35.

Parece que, antes da investigação dos sertões do Tibagi, já se supunha a existência de um território indígena. Morgado de Mateus justificou as expedições que organizou a partir de 1768 pelas: "continuas saídas do gentio, que ocupa os grandes Sertões do Tabagi há 9 anos a esta parte, tendo morto bastantes pessoas, e achando-se já muito próximos da es- 
trada, que vem da cidade de S. Paulo para estes Campos Gerais, e Rio Grande: as muitas fazendas, que se tem despovoado, e grandes riscos, que passam por esta estrada (...) movem ao Ilmo e Exmo Sr. General a mandar invadir o dito sertão, e aplicar os meios mais possíveis, para reduzir a êstes bárbaros". 29

A direção das ações indicava um local específico, os campos de Guarapuava, de onde se acreditava que esses índios saíssem. Os comandantes de Afonso Botelho foram direto para os campos e, em suas descrições e mapa, esmiuçaram o local. Referiram-se a uma grande área onde se espaIhavam roças, moradias e caminhos que interligavam uns núcleos a outros. Observaram um centro, para onde todas as comunicações convergiam. Indicaram que essa área se contrapunha a outras distantes. Acreditavam que fossem grupos étnicos diferentes, pois não havia trilhas interligando-as. Buscaram inferir os limites desse território. Assinalaram como áreas externas a esse perímetro os locais destituídos de marcas que comprovassem uma perambulação constante dos índios, o arranchamento que os indígenas não destruíram entre 1771/72 e 1773/74 e a aldeia que não se ligava por veredas ao que definiam como centro.

0 território que conceberam era formado pelas aldeias, roças, área de caça. Chegava até um dos acampamentos à beira do rio J ordão, onde Afonso Botelho e seus homens se estabeleceram em 1772 e de onde os índios desenterraram os soldados mortos no confronto acontecido naquela ocasião (Mapa 2, D). A entrada para os campos ficava onde Francisco Martin Lustosa, comandante da nona expedição, plantou uma roça em 1774. A meio caminho entre os Campos Gerais e os de Guarapuava, foi fundado, em 1771, o sítio Nossa Senhora da Esperança, que em 1773 já era freguesia. Aliás, este estabelecimento tinha visivelmente o papel de embaraçar a saída dos Xakclan, e a roça, o de viabilizar uma futura invasão desse território imaginado. Enfim, configuravam-se como pontos fixados para o seu cercamento.

Os comandantes narram a luta pelo território, indicada por símbolos fixados pelos soldados e, acreditam estes, retirados pelos índios. Os símbolos foram, entretanto, posteriormente, recolocados pelos soldados. $\mathrm{Na}$ décima primeira expedição, quando os soldados retornaram aos campos de Guarapuava, Paulo de Chaves de Almeida, comunicou a destruição parcial do acampamento próximo ao rio J ordão, empreendida - segundo supõe - pelos Xakclan. Esse comandante julgou que o acampamento estava dentro do que concebia como território indígena. Informou que os gentios haviam derrubado a cruz de madeira, um dos signos da posse colonial. $\mathrm{E}$ relatou o esforço que ele e seus homens fizeram para replantá-la na terra

29 Notícia da conquista e descobrimento dos sertões do Tibagi, p.77. 
e para gravar a inscrição Viva El Rei de Portugal: "em um grande pinheiro, que parece a natureza produziu para êste fim tão glorioso". ${ }^{30}$

Ao descrever a paisagem, os comandantes demarcaram um território Xakclan na fronteira, definido por parâmetros culturais próprios. Limitaram uma área, deixando marcos nas margens, um tronco de árvore com a inscrição Viva El Rei de Portugal, um arranchamento em ruínas, o princípio do que seria o cercamento de um forte e plantaram uma roça.

Inventaram um território conformado à sua noção de territorialidade e adequado aos seus interesses imediatos. Reconheceram como Xakclan o espaço físico ocupado materialmente pelos índios e as áreas adjacentes, que acreditavam, vigiadas por eles em Guarapuava. A colônia Brasil, entretanto, avançava além das terras concretamente apossadas e dominadas pelos súditos portugueses. Mais de dois terços da área total da colônia haviam sido apropriados simbolicamente por tratados fixados entre as metrópoles ibéricas e por cartas geográficas. Incorporavam ao território colonial, portanto, terras vazias de portugueses e de brasileiros. Contraditoriamente, identificavam como território indígena somente as terras que os Xakclan habitavam.

Ao se projetar sobre a organização espacial Kaingang e imaginar um território, os comandantes inverteram fenômenos históricos. Afirmaram que os índios invadiam as terras ocupadas por colonos ao longo da estrada para o Viamão. Entretanto, ainda estava em marcha, nessa porção da estrada dos tropeiros, a apropriação das terras por invernadores de gado. Portanto, era a fronteira indígena que estava sendo invadida e eram os colonos que avançavam sobre o sertão. Essa compreensão espelhada por parte dos portugueses e brasileiros revela uma deturpação do processo histórico em razão do desejo presente de apossamento daquelas terras e ganhou força e legitimidade com a decodificação da paisagem a partir de noções próprias de territorialidade. A área entre a estrada para o Viamão e o que entendiam como espaço físico dominado e ocupado pelos Kaingang (os campos de Guarapuava) era destituída de sinais que interpretavam como indicativos de território: roças, ranchos e caminhos interligando-os. Percebiam-na como terra devoluta e inculta.

Nas descrições produzidas pelos comandantes de Afonso Botelho e por ele próprio, a paisagem é naturalizada e esvaziada de gente, porque assim eles a decodificaram e porque eram caminhos abandonados pelos índios, afastados do que interpretavam como território indígena, que eles buscavam. Procuravam, nas trilhas percorridas, vestígios reveladores de posse e domínio da terra. Mas, à medida que possuíam informações sobre as direções a seguir e sobre o que encontrariam em seu trajeto, percebe-

30 Notícia da conquista e descobrimento dos sertões do Tibagi, p.280. 
se que os caminhos escolhidos esquivavam-se do que concebiam como territórios indígenas. A exceção eram os campos de Guarapuava, pois a meta das expedições era invadi-los e submeter os Xakclan. Assim, os soldados de Afonso Botelho mapearam e descreveram as veredas seguras a seguir, com poucas marcas que consideravam como interferência humana na paisagem.

A ausência de homens e mulheres e de cultura nesses cenários, portanto, é uma ilusão produzida pelo narrador devido a sua decodificação da paisagem e tendo em vista seus interesses imediatos. A existência de desertos validou e justificou a sua apropriação.

Entretanto, essas descrições nos revelaram que os cenários desertos dos sertões também foram um logro criado pelos índios. Está claro que estes abandonavam suas aldeias ao perceberem a chegada dos soldados e que os espreitavam em vários momentos. Mesmo durante a décima e a décima primeira expedição, que exploraram os campos de Guarapuava e situaram suas roças e aldeias, em poucas cenas os índios estavam presentes. A ausência era intencional. Os Xakclan se escondiam e os soldados tinham consciência desse fato. Se em algumas paisagens descritas está clara a fuga temporária por causa da aproximação inesperada dos homens de Afonso Botelho, um relato sugeriu que, diante da certeza do retorno futuro dos soldados, depois do confronto de 1772, os índios eliminaram as marcas de sua ocupação. Na décima primeira expedição, em 1774, quando 0 comandante Paulo de Chaves de Almeida regressou à aldeia que visitara a convite dos Xakclan dois anos antes, 0 arranchamento havia desaparecido: "se foram abarracar (...) cousa de uma légua distante do alojamento dos índios, que em 1772, se viu naquele lugar (...) Chegou ao sinalado lugar, aonde não achou mais que o chão, e a certeza de que ali fora, e já não existia". ${ }^{31}$ Portanto, o vazio humano em algumas descrições também foi um engodo criado pelos ausentes do cenário.

0 que esses relatórios nos mostram objetivamente é que os caminhos atravessados estavam relativamente afastados de aldeias indígenas e, especialmente, de áreas com densidade populacional considerada perigosa. Mas informam também que os índios evitavam se confrontar com os soldados, chegando a apagar vestígios de sua ocupação de um local e eliminando do cenário os elementos deduzidos como cultura.

Por essas mesmas narrativas, fica difícil afirmar que a fronteira era um espaço estático ou natural. Apesar das ausências, as paisagens retratadas apresentam sinais de variadas formas de ocupação e posse, ou seja, de interferências humanas na natureza e de histórias pretéritas. Foram áreas

31 Notícia da conquista e descobrimento dos sertões do Tibagi, p.280. 
indígenas, tomadas por espanhóis, destruídas por paulistas, retomadas ou deixadas pelos índios. Conhecidas pelos "antigos", sabida pelos novos.

Analisando as paisagens retratadas, levando em conta o que expõem objetivamente e o que está ausente ou apresentado parcialmente, conseguese entrever uma fronteira dinâmica. A agitação era marcada pela mobilidade física de sociedades indígenas e de colonos, de aldeias, de roças, de vilas e de caminhos - era cultural e ambiental. Do sertão, iam para a marinha, arcos, flechas, porongos, animais e frutas. Da marinha, vinham mercadorias para o sertão, ferro, facas, anzóis, casacos vermelhos. Cavalos, gado vacum, cachorros não raro ficaram perdidos no sertão e a malária se espalhava por obra de soldados desavisados.

As paisagens retratadas nessas descrições nos mostram que a fronteira era um local de múltiplos encontros, um espaço físico dinâmico, muito longe de uma natureza primitiva e intacta, afeta às leis naturais. É difícil de recuperar a dinâmica própria dessa área apenas pelo exame da documentação produzida pelos comandantes, uma vez que invariavelmente relatam a invasão do sertão e os seus efeitos a partir de sua visão de mundo. Dado o seu movimento, a fronteira é plural e seu desenvolvimento não é linear. Assim, questionamos que a realidade das fronteiras dos séculos XIX e XX possa ser projetada para o passado. O local onde se encontrava Vila Rica do Espírito Santo era sertão no início do século XVI, povoamento colonial espanhol no século XVII e sertão no século XVIII.

A crítica à concepção de que a fronteira era vazia ou escassa e desorganizadamente ocupada pelas sociedades indígenas não é novidade para a historiografia brasileira. Já foi apontado por vários intelectuais que, no início do século XX, quando a narrativa sobre o sertão foi construída, esta se ligava a um projeto de nação e a idealizações sobre as raízes da brasilidade. ${ }^{32}$ Entretanto, pouquíssimos historiadores forneceram dados que viabilizassem a reconstrução das descrições que se tinha sobre esse espaço. Essa representação de que a paisagem da fronteira do Brasil colônia era caracterizada por uma natureza virg em, o que leva à falsa premissa da existência de áreas intocadas, tem instruído discussões, recomendações de diretrizes e políticas públicas relativas à proteção ambiental. Estas têm contribuído para a tensão social existente, sobretudo em terras onde há a sobreposição de Unidades de Conservação e Terras Indígenas. ${ }^{33}$

32 AMADO, J anaína. Região, sertão, nação. Estudos Históricos, Rio de J aneiro, v.8, n.15, p.145-151, 1995; LEONíDIO, Adalmir. O sertão e "outros lugares": a idéia der nação em Paulo Prado e Manoel Bonfim. In: ALMEIDA, Ângela Mendes de; ZILLY, Berthold; LIMA, Eli Napoleão. (ed.) De sertões, desertos e espaços incivilizados. Rio de J aneiro: Mauad, 2001, p.21-34; LIMA, Nísia Trindade. Um sertão chamado Brasil. Rio de J aneiro: Renavam/ IUPERJ / UCAM, 1999; OLIVEIRA, Lúcia Lippi. Americanos. Representações da identidade nacional no Brasil e nos E.U.A. Belo Horizonte: Ed. UFMG, 2000; SENA, Selma Custódio. A categoria sertão: um exercício de imaginação antropológica. Sociedade e cultura. Revista de Ciências Sociais, Goiás, v.1, n.1, p.19-28, jan/jun.1998; VANGELISTA, Chiara. Terra e fronteira no Brasil: culturas, etnias, sociedade.

33 Essa questão é refletida por antropólogos e ambientalistas numa iniciativa muito interessante que resultou no livro: RICARDO, Fany. (org.) Terras indígenas e Unidades de Conservação da natureza. 0 desafio das sobreposições. 
Reconstruir a narrativa sobre o cenário colonial é uma das várias ações a se empreender para orientar a discussão sobre justiça social e equilíbrio ambiental. 